\title{
Erratum to: Evaluation of the operating parameters of the liquid sampling-atmospheric pressure glow discharge (LS-APGD) ionization source for elemental mass spectrometry
}

Lynn X. Zhang • Benjamin T. Manard •

Stefanie Konegger-Kappel • R. Kenneth Marcus

Received: 16 July 2014 / Accepted: 16 July 2014 / Published online: 21 August 2014

(C) Springer-Verlag Berlin Heidelberg 2014

Erratum to: Anal Bioanal Chem

DOI 10.1007/s00216-014-7990-6

The authors would like to call your attention to the fact that unfortunately one author name was misspelled in the original publication: it should be Stefanie Konegger-Kappel.

Published in the topical collection Emerging Concepts and Strategies in Analytical Glow Discharges with guest editors Rosario Pereiro and Steven Ray.

The online version of the original article can be found at http://dx.doi.org/ 10.1007/s00216-014-7990-6.

L. X. Zhang $\cdot$ B. T. Manard · S. Konegger-Kappel •

R. K. Marcus $(\bowtie)$

Department of Chemistry, Clemson University, Clemson, SC 29634,

USA

e-mail: marcusr@clemson.edu 